\title{
Enkephalin Convertase: Localization to Specific Neuronal Pathways
}

\author{
David R. Lynch, Stephen M. Strittmatter, J. Clark Venable, and Solomon H. Snyder \\ Departments of Neuroscience, Pharmacology and Experimental Therapeutics, Psychiatry and Behavioral Sciences, \\ The Johns Hopkins University School of Medicine, Baltimore, Maryland 21205
}

\begin{abstract}
${ }^{3}$ H-Guanidinoethylmercaptosuccinic acid (GEMSA) selectively labels the carboxypeptidase B-like enzyme enkephalin convertase (EC) in rat brain tissue sections. We have used autoradiography with ${ }^{3} \mathrm{H}$-GEMSA to map membrane-bound $\mathrm{EC}$ in the rat forebrain and, in conjunction with lesioning techniques, to localize EC to specific neuronal pathways. The highest levels of EC are in the median eminence. High levels of EC also occur in the hypothalamic magnocellular nuclei, in several nuclei of the amygdala, the lateral septum, and the bed nuclei of the stria terminalis. Knife-cut lesions of the stria terminalis increase EC posterior to the lesion in the stria and deplete EC from the stria adjacent to the bed nucleus, suggesting that $\mathrm{EC}$, like enkephalins, is axonally transported within the stria terminalis. Ibotenic acid lesions of the caudate nucleus destroy binding in the substantia nigra pars reticulata ipsilateral to the lesion, suggesting that nigral EC is associated with axons originating in the caudate nucleus. We have also mapped $\mathrm{EC}$ in detail in the hippocampus. EC levels are highest near pyramidal cells of $C A$ 3-4 and the dentate gyrus granule cells. Quinolinic acid lesions destroy both the granule and pyramidal cells and destroy all of the ${ }^{3}$ H-GEMSA labeling except for a small amount in the molecular layer of the dentate gyrus. Selective destruction of $\mathbf{C A}$ 3-4 pyramidal cells with kainic acid eliminates $\mathrm{EC}$ in the pyramidal cell region. Destruction of granule cells of the dentate gyrus with colchicine depletes binding in the dentate gyrus without any change in the area surrounding field $\mathrm{CA}$ 3-4. High levels of ${ }^{3} \mathrm{H}$-GEMSA binding are present in the hippocampus at least $3 \mathrm{~d}$ before birth. These observations suggest that in the hippocampus the majority of EC is associated with pyramidal cells, which have not been shown to contain enkephalins. ${ }^{3} \mathbf{H}$ GEMSA autoradiography of the trigeminal ganglion localizes $\mathrm{EC}$ to the sensory neurons and not to white matter tracts there. These studies demonstrate that while $\mathrm{EC}$ is contained in enkephalinergic pathways, it is also present in some neurons that do not contain enkephalins.
\end{abstract}

Peptide neurotransmitters and hormones are commonly synthesized as long precursors in which the active peptide is flanked by dibasic amino acids (Docherty and Steiner, 1982). The sequential actions of an endopeptidase followed by a carboxy-

\footnotetext{
Received July 25, 1985; revised Oct. 4, 1985; accepted Oct. 9, 1985.

We wish to thank Drs. Paul Worley and Jay Baraban for help with the lesioning experiments, Drs. Reinhard Grzanna and George Uhl for helpful discussions, Naomi Taylor and Virginia Wilson for excellent technical assistance, and Dawn C. Dodson for secretarial assistance. Supported by USPHS Grants DA-00266, NS-16375, Research Scientist Award DA-00074 (S.H.S.), and Training Grant GM-07309 (D.R.L., S.M.S.).

Correspondence should be addressed to Solomon H. Snyder, Department of Neuroscience, The Johns Hopkins University School of Medicine, 725 North Wolfe Street, Baltimore, MD 21205.

Copyright $@ 1986$ Society for Neuroscience $0270-6474 / 86 / 061662-14 \$ 02.00 / 0$
}

peptidase $B$-like enzyme are capable of releasing the active peptide from the precursor. The sequences of 2 putative precursors of the enkephalins, designated proenkephalin $A$ and proenkephalin B/prodynorphin, have a similar structure, in which multiple copies of Leu- or Met-enkephalin are flanked by 2 basic amino acids (Comb et al., 1982; Gulber et al., 1982; Kakidani et al., 1982; Noda et al., 1982). Proenkephalin A contains 4 copies of Met-enkephalin and 1 of Leu-enkephalin flanked by dibasic amino acids. Proenkephalin B/prodynorphin contains 3 copies of Leu-enkephalin, each of which is contained within one of the longer opioid peptides dynorphin, the neoendorphins, or rimorphin. Recent evidence has suggested that these precursors are processed to different products in different areas of the body. While proenkephalin $A$ is processed to the enkephalins in the brain, in the adrenal it produces higher molecular weight peptides containing enkephalin (Boarder et al., 1982; Kimura et al., 1980; Lewis et al., 1979). Levels of the various proenkephalin $B /$ prodynorphin-derived peptides vary regionally within the brain, suggesting that processing of proenkephalin B displays similar variations (Seizinger et al., 1984; Zamir et al., 1984a). Thus, the activity of processing enzymes in different tissues or brain regions should affect which opioid peptides are formed from a given precursor in a specific location.

Such tissue-specific and regional-processing differences highlight the importance of identifying the enzymes that process enkephalin precursors. In proenkephalin processing, the sequential action of a trypsin-like enzyme, and a carboxypeptidase B-like enzyme can release mature peptide from its position flanked by dibasic sequences. The carboxypeptidase B-like enzyme directly forms enkephalins by releasing basic amino acids from the carboxyl terminus of the products of a trypsin-like cleavage. We have previously described a novel carboxypeptidase B-like enzyme termed enkephalin convertase (EC) (EC 3.14.17.10) that may act physiologically in the processing of enkephalins. It has an optimum $\mathrm{pH}$ of 5.5 , is present in both membrane and soluble forms, and has been colocalized with enkephalins in adrenal chromaffin granules (Fricker and Snyder, 1982, 1983; Supattapone et al., 1984). EC is inhibited potently and selectively by guanidinoethylmercaptosuccinic acid (GEMSA) with a $K_{\mathrm{i}}$ of about 5 nM (Fricker et al., 1983). GEMSA has a $K_{\mathrm{i}}$ for other carboxypeptidase B-like enzymes of greater than $1 \mu \mathrm{M}$ so that at low concentrations GEMSA interacts selectively with EC. ${ }^{3} \mathrm{H}$-GEMSA binds only to EC under assay conditions we described previously in both homogenates and in tissue sections (Lynch et al., 1984; Strittmatter et al., 1984b).

We used the specificity of ${ }^{3} \mathrm{H}$-GEMSA for EC to localize the membrane bound form of $\mathrm{EC}$ in the brain by in vitro autoradiography. The distribution of $\mathrm{EC}$ in a variety of brain regions generally parallels that of enkephalins (Lynch et al., 1984). However, our previous study did not assess whether EC is found in the same neuronal pathways as enkephalins. Enkephalins have 
A
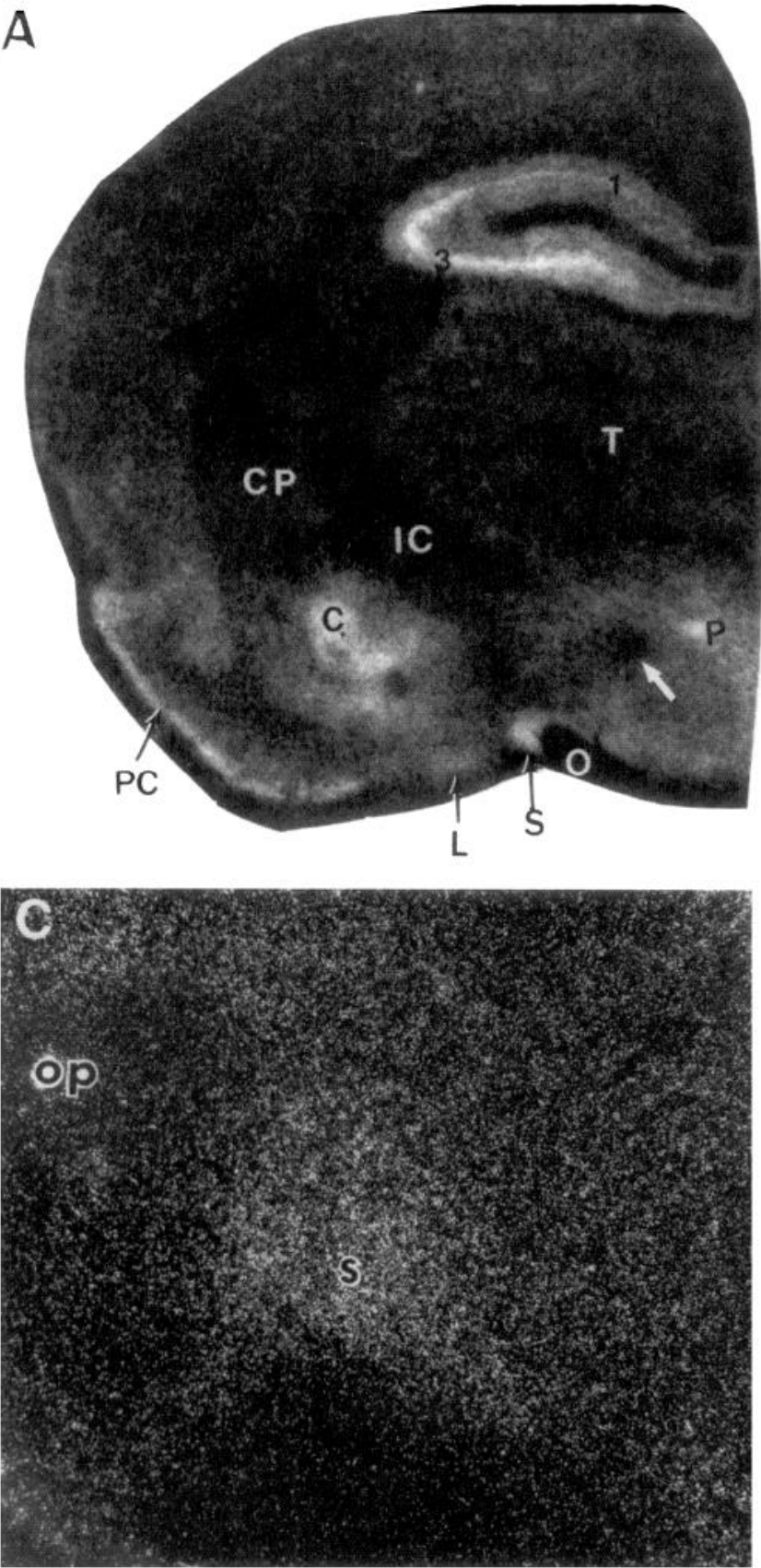
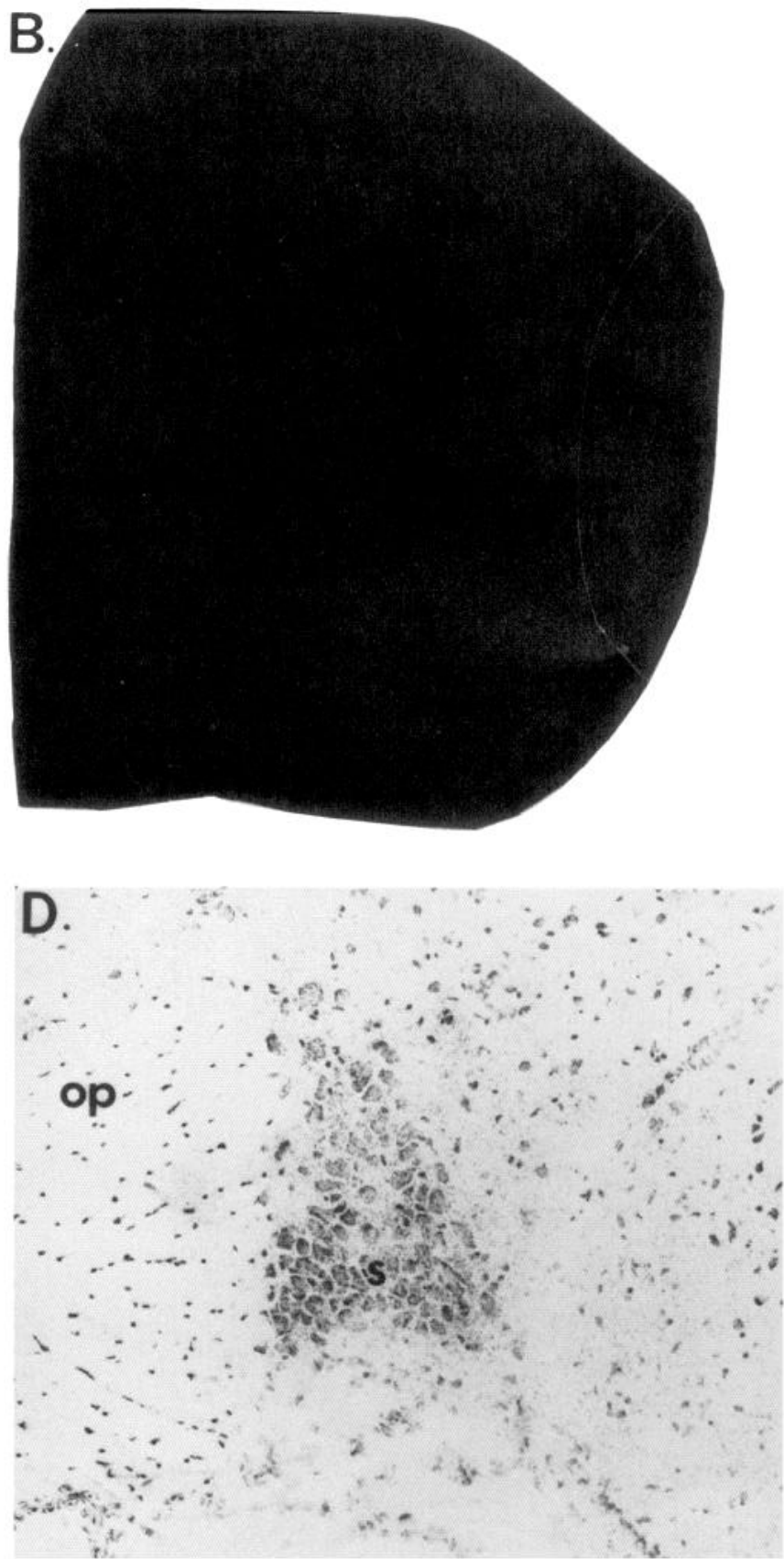

Figure 1. ${ }^{3} \mathrm{H}$-GEMSA binding in rat forebrain. ${ }^{3} \mathrm{H}$-GEMSA autoradiography was performed as described under Materials and Methods. A, Halfsection incubated with $1.5 \mathrm{nM}{ }^{3} \mathrm{H}$-GEMSA. $B$, Matching half-section incubated with $1.5 \mathrm{nM}{ }^{3} \mathrm{H}-\mathrm{GEMSA}$ and $10 \mu \mathrm{M}$ unlabeled GEMSA. White areas indicate areas of high binding. Binding is high in the supraoptic $(S)$ and paraventricular $(P)$ nuclei of the hypothalamus, the primary olfactory cortex $(P C)$, the nucleus of the lateral olfactory tract $(L)$, the central nucleus of the amygdala $(c)$, and the CA 3 region of the hippocampus $(3)$. Binding is moderate in the CA 1 field of the hippocampus $(1)$, the thalamus $(T)$, and the caudate-putamen $(C P)$. Binding is low in white matter areas such as the internal capsule (IC) and the fornix (arrow). Panels $C$ and $D$ demonstrate high levels of binding in the supraoptic nucleus, with $C$ showing autoradiographic grains and $D$ tissue staining with toluidine blue.

been localized to certain discrete pathways in the brain, including the stria terminalis (Uhl et al., 1978) and a striatonigral pathway (Correa et al., 1981; Cuello and Paxinos, 1978). Proenkephalin B-derived peptides are found within the mossy fiber pathway in the hippocampus (McGinty et al., 1983). In the present study we have extended our previous findings by using lesioning techniques to localize EC to specific neuronal pathways. In addition, we have mapped the distribution of EC in detail within the rat forebrain and especially within the hippocampus.

\section{Materials and Methods}

\section{Materials}

${ }^{3} \mathrm{H}$-GEMSA was obtained from New England Nuclear (Boston), unlabeled GEMSA from Calbiochem (La Jolla, CA), and colchicine and kainic acid from Sigma (St. Louis).

\section{${ }^{3} H$-GEMSA autoradiography}

The method for ${ }^{3} \mathrm{H}$-GEMSA autoradiography has been described previously (Lynch et al., 1984). For routine experiments, $8 \mu \mathrm{m}$ cryostat 
Table 1. Distribution of ${ }^{3}$ H-GEMSA binding in the rat forebrain

${ }^{3}$ H-GEMSA

bound

Region

(fmol/mg protein)

Caudate-putamen

$39 \pm 2$

Globus pallidus

Lateral septum

Medial septum

Claustrum/endopiriform nucleus

Ventral pallidum

Nucleus of the diagonal band

Olfactory tubercle

Bed nucleus of the stria terminalis

Dorsal

Ventral

Frontal/parietal cortex

Primary olfactory cortex

Entorhinal cortex

Hippocampus

CA 3-4 pyramidal layer

CA 1-2 pyramidal layer

$42 \pm 3$

$105 \pm 6$

$63 \pm 4$

$85 \pm 4$

$65 \pm 3$

$74 \pm 4$

$66 \pm 3$

$97 \pm 6$

$100 \pm 7$

$51 \pm 3$

$85 \pm 3$

$79 \pm 6$

$89 \pm 3$

$73 \pm 4$

$76 \pm 4$

$93 \pm 6$

$60 \pm 4$

$73 \pm 9$

$88 \pm 6$

$91 \pm 9$

$64 \pm 5$

$60 \pm 6$

$81 \pm 5$

$84 \pm 5$

$98 \pm 4$

$76 \pm 5$

$60 \pm 6$

$78 \pm 4$

$50 \pm 3$

Lateral

Paraventricular

Magnocellular

Parvocellular

Supraoptic

Arcuate

Ventromedial

Dorsomedial

Dorsal

Posterior

Premammillary nucleus

Supramammillary nucleus

Medial mammillary nucleus

Median eminence

Thalamus

Paraventricular

Centromedian

Reuniens

Reticular

Medial dorsal

Ventral lateral

Ventral posterior

$90 \pm 6$

$73 \pm 12$

$95 \pm 9$

$85 \pm 4$

$78 \pm 6$

$87 \pm 5$

$57 \pm 3$

$57 \pm 4$

$82 \pm 3$

$61 \pm 8$

$54 \pm 8$

$110 \pm 11$

$55 \pm 2$

$48 \pm 4$

$53 \pm 5$

$37 \pm 3$

$38 \pm 5$

$38 \pm 5$

$33 \pm 3$
Table 1. Continued

\begin{tabular}{lc} 
Region & $\begin{array}{l}{ }^{3} \text { H-GEMSA } \\
\text { bound } \\
\text { (fmol/mg protein) }\end{array}$ \\
\hline Ventral medial & $27 \pm 1$ \\
Lateral dorsal & $32 \pm 1$ \\
Lateral posterior & $36 \pm 3$ \\
Anterior & $40 \pm 1$ \\
Paratenial & $48 \pm 3$ \\
Posterior & $38 \pm 3$ \\
Lateral geniculate & $49 \pm 2$ \\
Medial habenula & $58 \pm 3$ \\
Lateral habenula & $44 \pm 3$ \\
Subthalamic nucleus & $46 \pm 3$ \\
Zona incerta & $28 \pm 2$ \\
White matter & \\
Stria terminalis & $62 \pm 9$ \\
Fornix & $30 \pm 4$ \\
Anterior commissure & $19 \pm 4$ \\
Corpus callosum & $25 \pm 1$ \\
Stria medullaris & $12 \pm 2$ \\
Internal capsule & $22 \pm 5$ \\
Medial lemniscus & $22 \pm 2$ \\
\hline
\end{tabular}

Cryostat sections, $8 \mu \mathrm{m}$, were incubated in $0.75 \mathrm{~nm}{ }^{3} \mathrm{H}$-GEMSA and exposed as described in Materials and Methods. Autoradiograms generated were quantitated using a computer-assisted image-analysis system. Values are reported as the mean of at least three sections \pm SEM. Given the $K_{\mathrm{D}}$ of EC for ${ }^{3} \mathrm{H}-\mathrm{GEMSA}$ of $\sim 10 \mathrm{nM}$, $B_{\max }$ values for ${ }^{3} \mathrm{H}$-GEMSA would be approximately 20 -fold higher in each region than the values shown.

sections were incubated for $5 \mathrm{~min}$ at $4^{\circ} \mathrm{C}$ in $50 \mathrm{~mm}$ sodium acetate, pH 5.5 , followed by incubation for $30 \mathrm{~min}$ in the same buffer with labeled GEMSA and any inhibitors. The sections were washed twice for $1 \mathrm{~min}$ in the same buffer and dried under a stream of cool air. Nonspecific binding was determined by incubation in the presence of $10 \mu \mathrm{M}$ unlabeled GEMSA. The ${ }^{3} \mathrm{H}-$ GEMSA concentration was 0.75 or $1.5 \mathrm{nM}$ for routine experiments. Sections were exposed to LKB ultrafilm for approximately $16 \mathrm{~d}$ or to emulsion-coated coverslips for about 3 weeks. Autoradiograms were quantitated using a computer-assisted imageanalysis system (Kuhar et al., 1984) and converted to picomoles ${ }^{3} \mathrm{H}$ GEMSA bound per milligram protein using standards (Unnerstall et al., 1982). Following autoradiography, sections were stained with toluidine blue.

Cholinesterase staining was performed by the method of Ralis et al. (1973)

\section{Animals}

Male Sprague-Dawley rats, 175-200 gm, were prepared for autoradiography and perfused with phosphate-buffered sucrose and no fixative as described previously (Young and Kuhar, 1979). For studies with neonatal rats, the rats were not perfused; instead, the rats were decapitated and the brain removed, mounted in brain paste, and frozen rapidly on dry ice.

\section{Lesioning techniques}

Knife-cut lesions of the stria terminalis were conducted as described previously by Uhl et al. (1978). In this method, a knife was stereotaxically lowered through the skull so as to sever the stria terminalis horizontally and unilaterally.

Lesions of both the pyramidal and granule cells of the hippocampal formation were conducted by intrahippocampal injection of $200 \mathrm{nmol}$ of quinolinic acid (Schwarz et al., 1983). Animals were sacrificed $4 \mathrm{~d}$ later, and tissue staining confirmed the destruction of both the bippocampal pyramidal cells and the dentate gyrus granule cells. CA 3-4 pyramidal cells were lesioned by a modification of the method of MoGinty et al. (1983) in which $1 \mu \mathrm{g}$ of kainic acid was injected intrahippocampally. Animals were sacrificed 3-4 d later. Granule cells were lesioned 

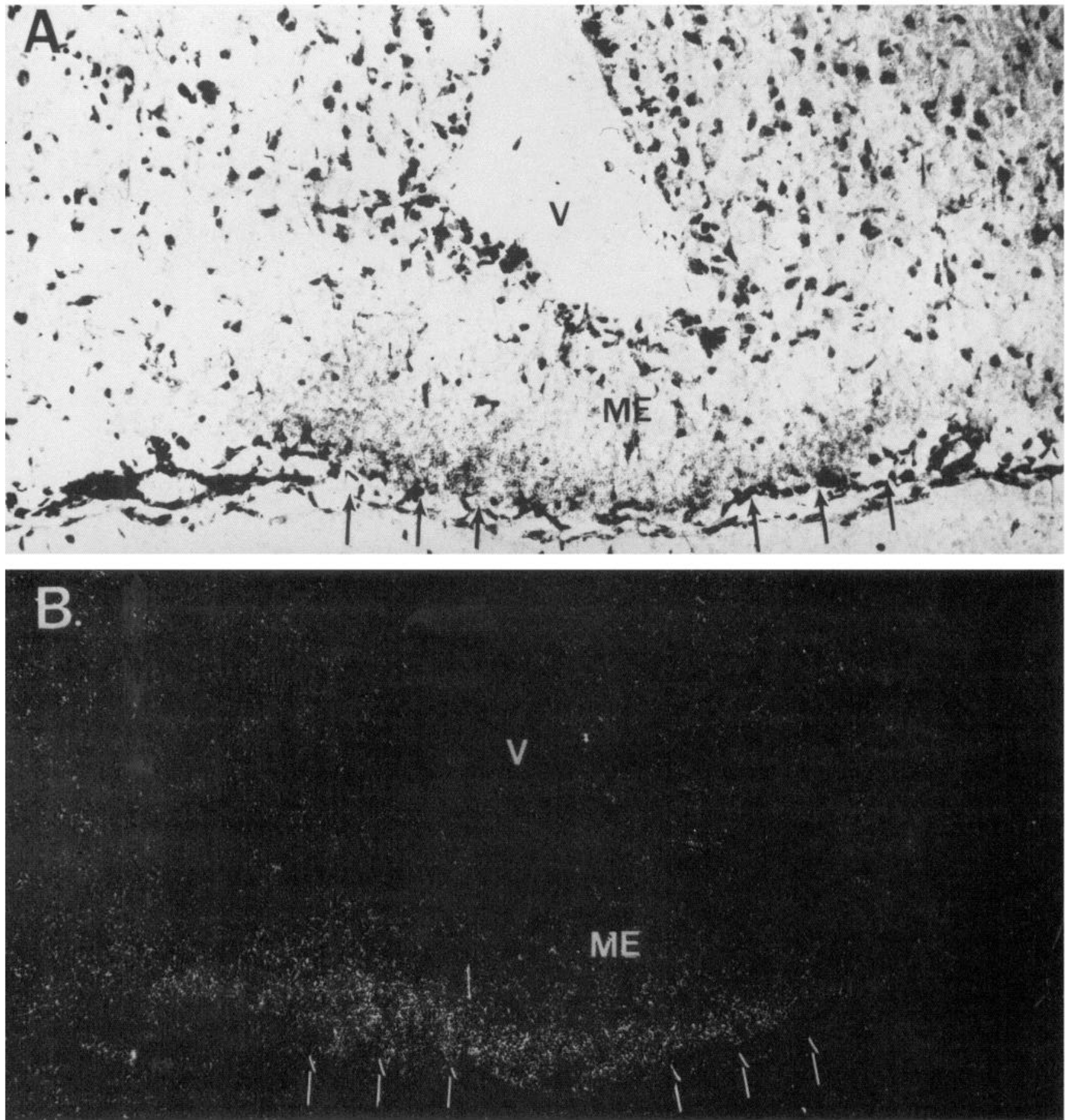

Figure 2. ${ }^{3} \mathrm{H}-$ GEMSA binding in the median eminence. The highest levels of ${ }^{3} \mathrm{H}-\mathrm{GEMSA}$ binding in the brain are in the median eminence ( $M E$ ), where they are found in the outer zone (arrows). $V$, third ventricle.

by the method of McGinty et al. (1983), in which $3 \mu \mathrm{g}$ of colchicine was injected into the dorsal and ventral hila of the hippocampus. Animals were sacrificed $8 \mathrm{~d}$ later. In all of these lesions, the opposite side was injected with saline to serve as a control for the lesioned side.

Lesions of the striatonigral pathway with ibotenic acid were performed as described previously by Strittmatter et al. (1984a), and animals were sacrificed after $14 \mathrm{~d}$.

\section{Results}

The specificity of ${ }^{3} \mathrm{H}$-GEMSA for EC has been demonstrated previously in tissue sections (Lynch et al., 1984). Its binding to tissue sections has a pharmacological profile that matches that of EC catalytic activity. Binding to tissue sections is saturable with a $K_{\mathrm{D}}$ of about $5 \mathrm{nM}$, which is consistent with the potent inhibition of EC activity by GEMSA. In conjunction with the specific interaction of GEMSA with EC enzymatically and in homogenate binding, these findings indicate that ${ }^{3} \mathrm{H}$-GEMSA labels only EC in tissue sections. Nonspecific binding (Fig. 1B) is negligible, so that all grains observed represent specific binding to EC.

Selected regions with high levels of ${ }^{3} \mathrm{H}-$ GEMSA binding have been examined at higher resolution than our previous study 

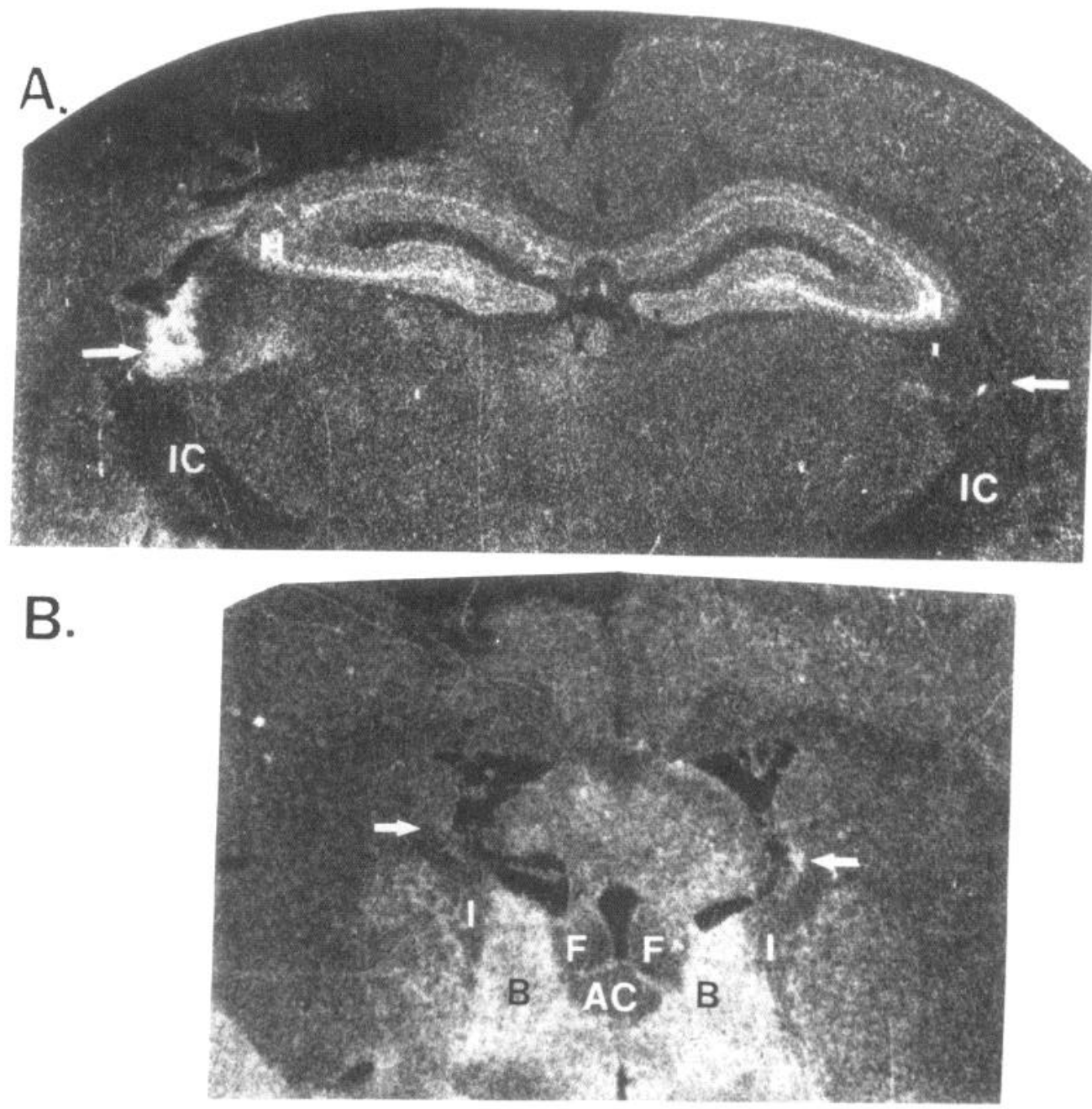

Figure 3. Enkephalin convertase in lesions of the stria terminalis. The stria terminalis was unilaterally transected on the left as described under Materials and Methods. $A,{ }^{3} \mathrm{H}-$ GEMSA autoradiogram of a section behind the cut with an accumulation of EC in the stria terminalis (arrow) ipsilaterally behind the transection; no effect on $\mathrm{EC}$ is seen in the hippocampus $(H)$ or cerebral cortex. $B$, Section in front of the transection demonstrating a depletion of EC within the stria terminalis (arrow) ipsilateral to the lesion (left) and adjacent to the bed nucleus of the stria terminalis $(B)$ but not within the internal capsule (IC), the fornix $(F)$, or anterior commissure $(A C)$. The reproducibility of the labeling in this portion of the stria is shown in a similar section from an unlesioned animal $(C)$.

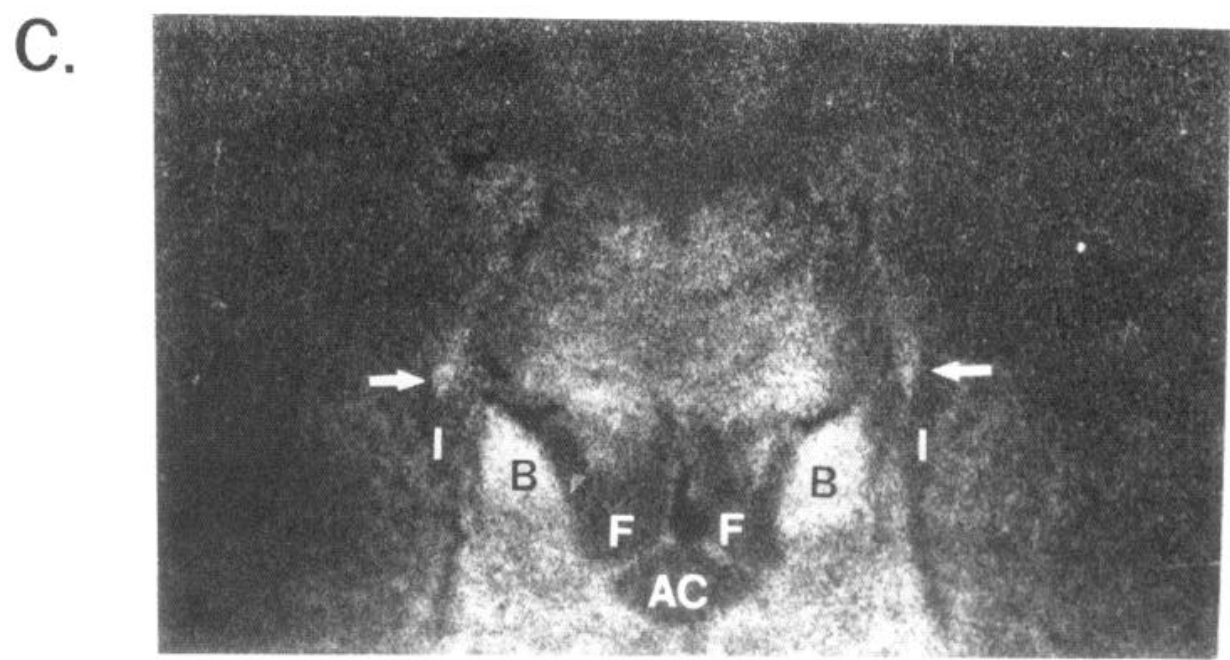

(Fig. 1), and the distribution of membrane EC has been determined in detail in the rat forebrain (Table 1). EC levels are highest in the median eminence (Fig. 2), where EC is mainly found in the outer zone. In the diencephalon, EC levels are greater in the hypothalamus than in the thalamus, with particularly high levels in the magnocellular nuclei. Several of the amygdaloid nuclei have high levels of EC, especially the central and posterior cortical nuclei. EC levels are high in limbic system areas, including the lateral septum, the bed nucleus of the stria terminalis, and the hippocampus. EC is distributed heterogeneously in the cerebral cortex, with the primary olfactory and entorhinal cortex having higher levels than the parietal or frontal cortex.

Using lesion studies in conjunction with autoradiography, we have obtained evidence that EC occurs in specific pathways. After transection of the stria terminalis, EC levels are increased posterior to the lesion in the stria and depleted from the stria adjacent to the bed nucleus (Fig. 3). The unilateral depletion in 


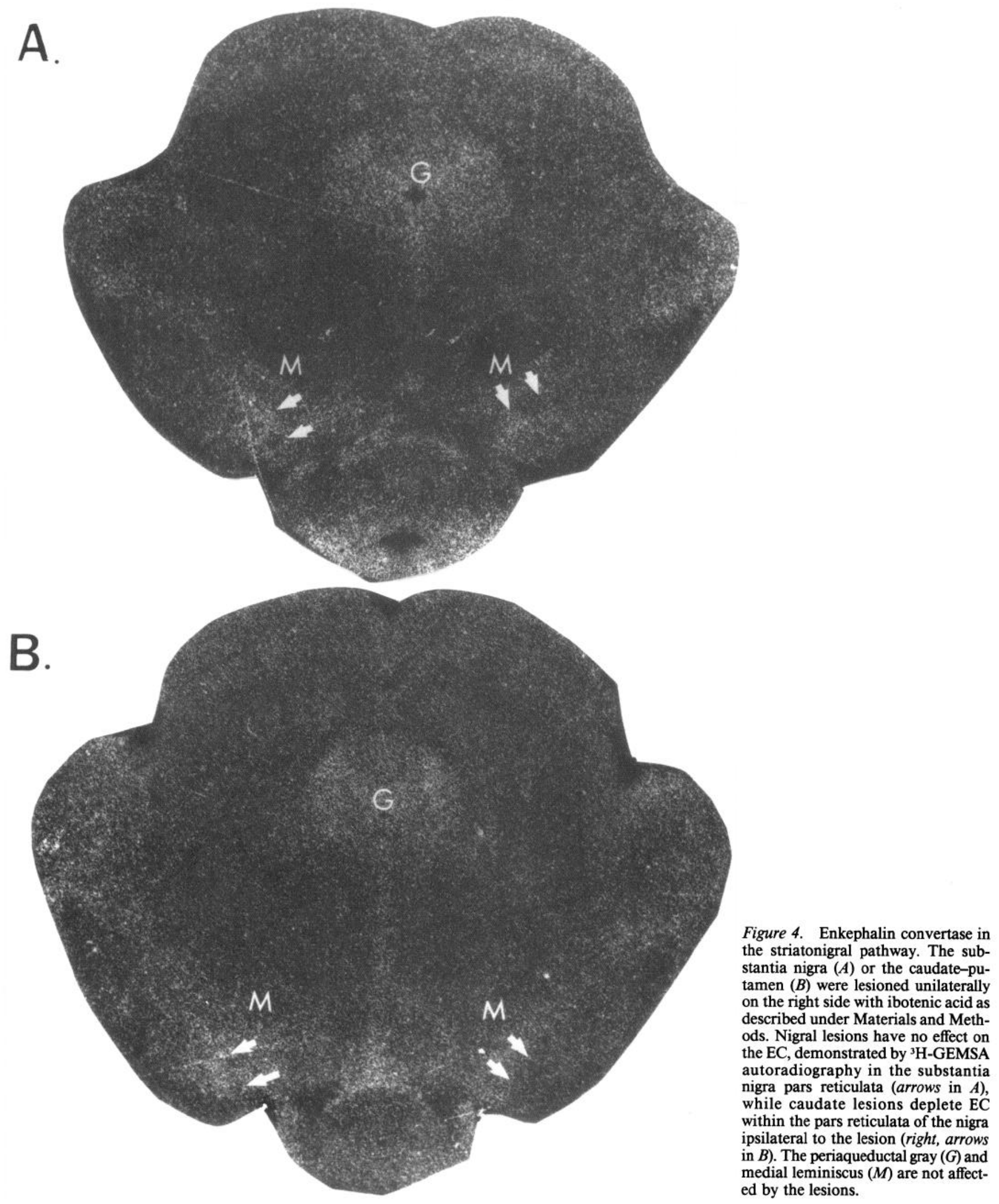

${ }^{3} \mathrm{H}$-GEMSA binding in the rostral portion of the stria is incomplete (Fig. 3B). EC levels are not affected in the cerebral cortex disrupted on the lesioned side, demonstrating the specificity of this effect for the stria terminalis.
EC levels are low in the caudate nucleus and moderate in the globus pallidus and substantia nigra pars reticulata. Lesioning the caudate nucleus with ibotenic acid destroys binding in the substantia nigra pars reticulata ipsilateral to the lesion but not 

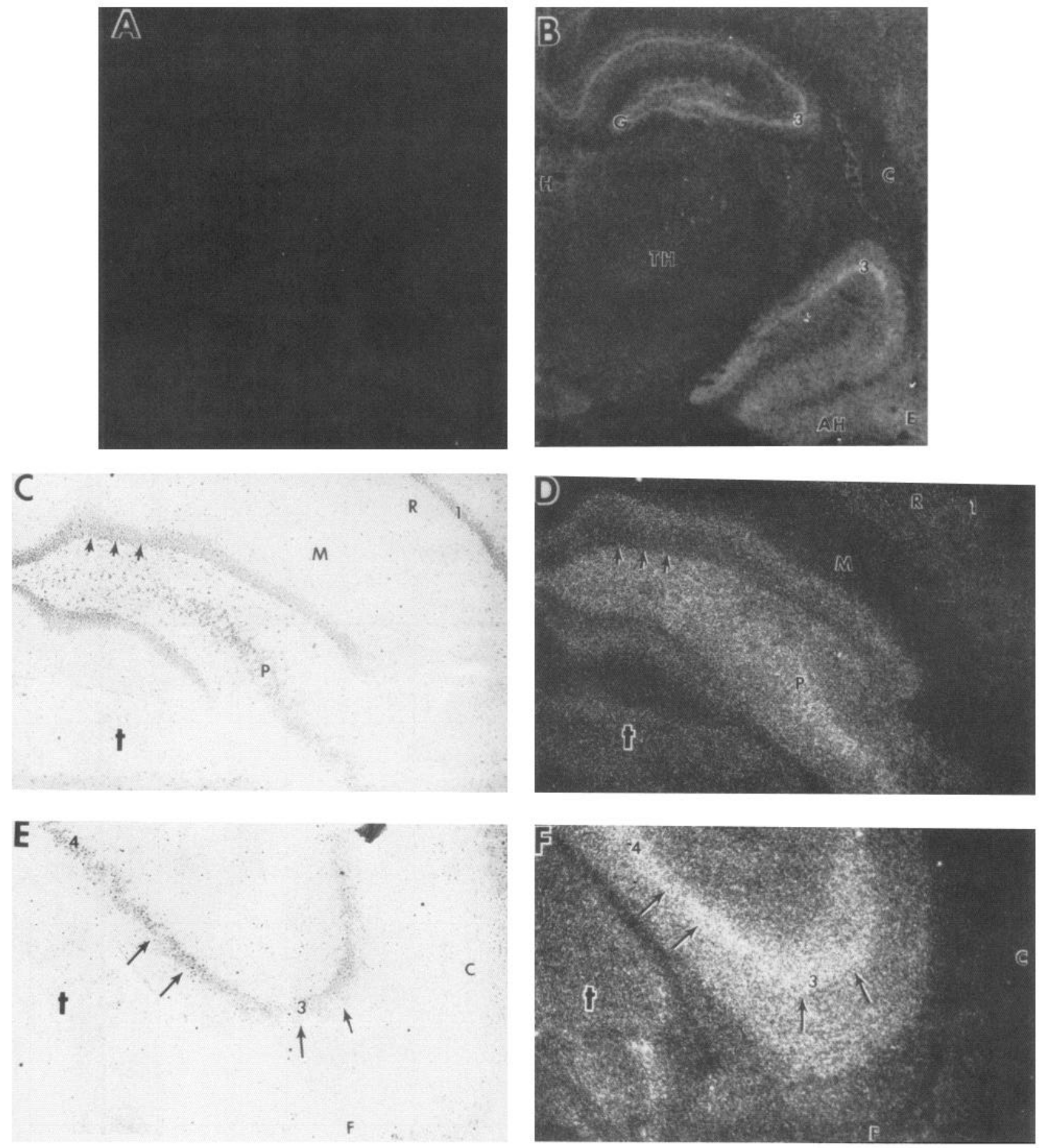

Figure 5. Enkephalin convertase in the hippocampal formation. $A$, Section through the hippocampus incubated with $1.5 \mathrm{nM}{ }^{3} \mathrm{H}-\mathrm{GEMSA}$ and 10 $\mu \mathrm{M}$ unlabeled GEMSA. $B$, Identical section incubated in $1.5 \mathrm{~nm}{ }^{3} \mathrm{H}$-GEMSA alone. Specific labeling is found in both the dentate gyrus $(G)$ and the hippocampus, particularly CA 3 (3). Labeling is also found in the entorhinal cortex $(E)$ and the amygdalohippocampal area $(A H)$, with lower levels in the habenula $(H)$, thalamus $(T)$, and external capsule $(C)$. At higher power ( $C$, tissue staining; $D$, autoradiographic grains), the grains in the dentate gyrus are found mainly in the inner part of the molecular layer $(M)$ and in lower levels directly over the granule cells (arrows). High labeling is also found over the pyramidal cells $(P)$, with lower levels in the stratum radiatum $(R)$ and CA $1(1)$ area and in the adjacent part of the thalamus $(t)$. In the hippocampus ( $E$, tissue staining; $F$, autoradiography grains), the grains are directly over the pyramidal cells of CA 3 (3) and CA 4 (4), with lower levels over the dendritic fields of the pyramidal cells. Lower levels of binding are seen in the fornix $(F)$, the adjacent thalamus $(T)$, and the external capsule $(c)$.

contralateral to it (Fig. 4). This suggests that nigral EC is associated with axons originating in the caudate nucleus. Injection of ibotenic acid in the substantia nigra does not affect ${ }^{3} \mathrm{H}-\mathrm{GEM}-$ SA binding there (Fig. 4), confirming that nigral EC is associated with extrinsic cell bodies and not nigral neurons.

\section{Distribution of EC in the hippocampal formation}

Both homogenate binding (Strittmatter et al., 1984) and autoradiography reveal the presence of high levels of ${ }^{3} \mathrm{H}-\mathrm{GEMSA}$ binding in the hippocampus. EC levels in the hippocampus (Fig. 

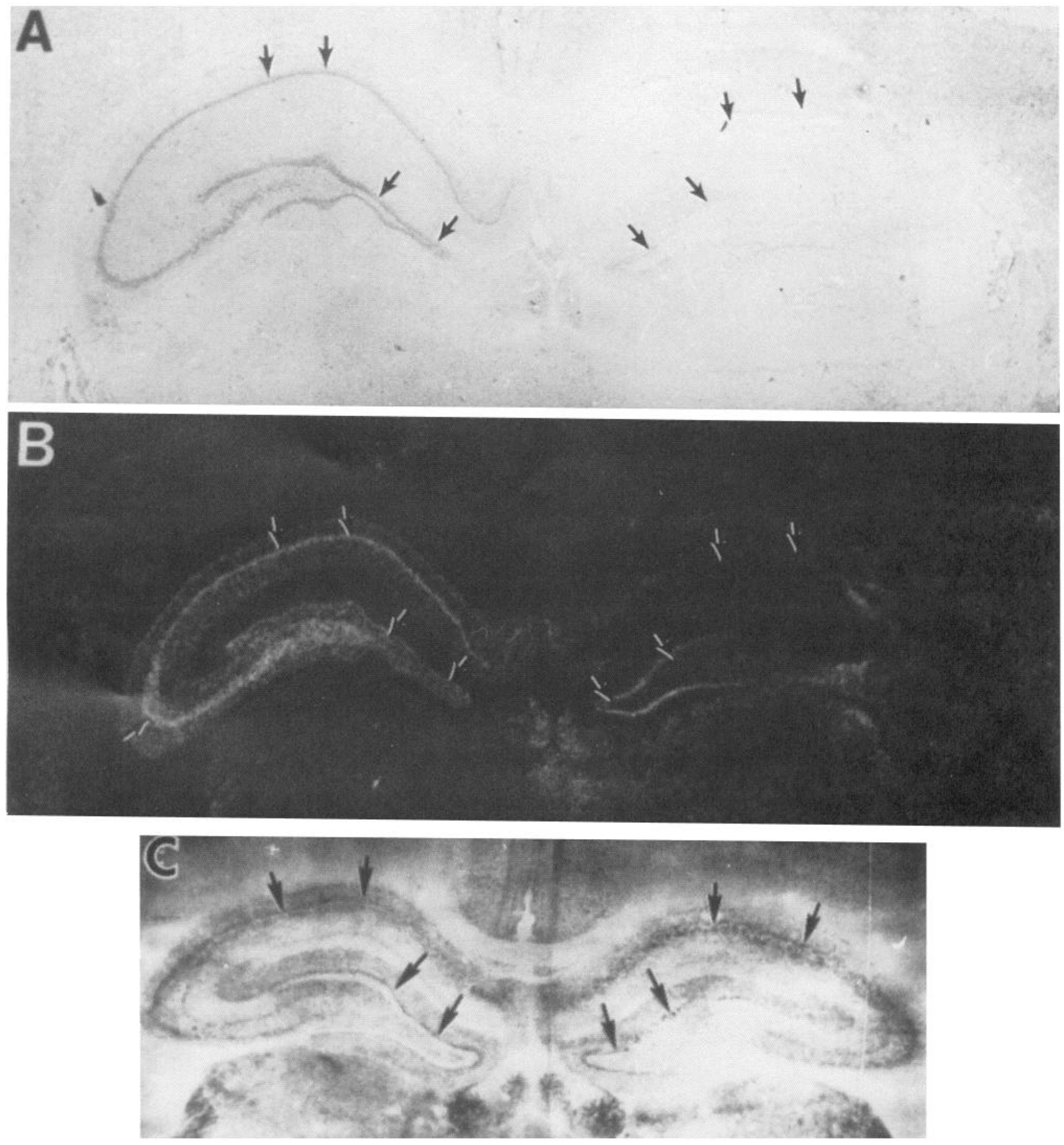

Figure 6. Enkephalin convertase in the intrinsic hippocampal neurons. The hippocampus was lesioned unilaterally on the right side with quinolinic acid as described in Materials and Methods. The lesion destroyed both the granule cells and the pyramidal cells, as shown by toluidine blue staining $(A)$ and abolished the ${ }^{3} \mathrm{H}$-GEMSA binding $(B)$ except for a small amount in the molecular layer of the dentate gyrus. Cholinesterase staining $(C)$ showed that the hippocampal afferents were left intact.

5) are highest around the pyramidal cells, especially CA 3-4, and the granule cells of the dentate gyrus. Lower levels are found in both the stratum oriens and the stratum radiatum of the hippocampus. At higher magnification, ${ }^{3} \mathrm{H}$-GEMSA-associated grains appear directly over the pyramidal cells in the hippocampus and over the granule cells and the innermost portion of the molecular layer in the dentate gyrus. One interpretation of these data is that EC here is largely in the mossy fiber pathway, which projects from the dentate gyrus to the stratum lucidum around
CA 3-4. Lesioning studies demonstrate a more complex distribution of EC here.

Quinolinic acid lesions destroy both the granule and pyramidal cells by histologic criteria, while cholinesterase staining confirms that hippocampal afferents are left intact by this lesion (Fig. 6). With the exception of a thin layer of binding in the inner portion of the molecular layer of the dentate gyrus, ${ }^{3} \mathrm{H}$ GEMSA-associated grains are eliminated. Thus, except for a few afferents terminating in the inner portion of the molecular 


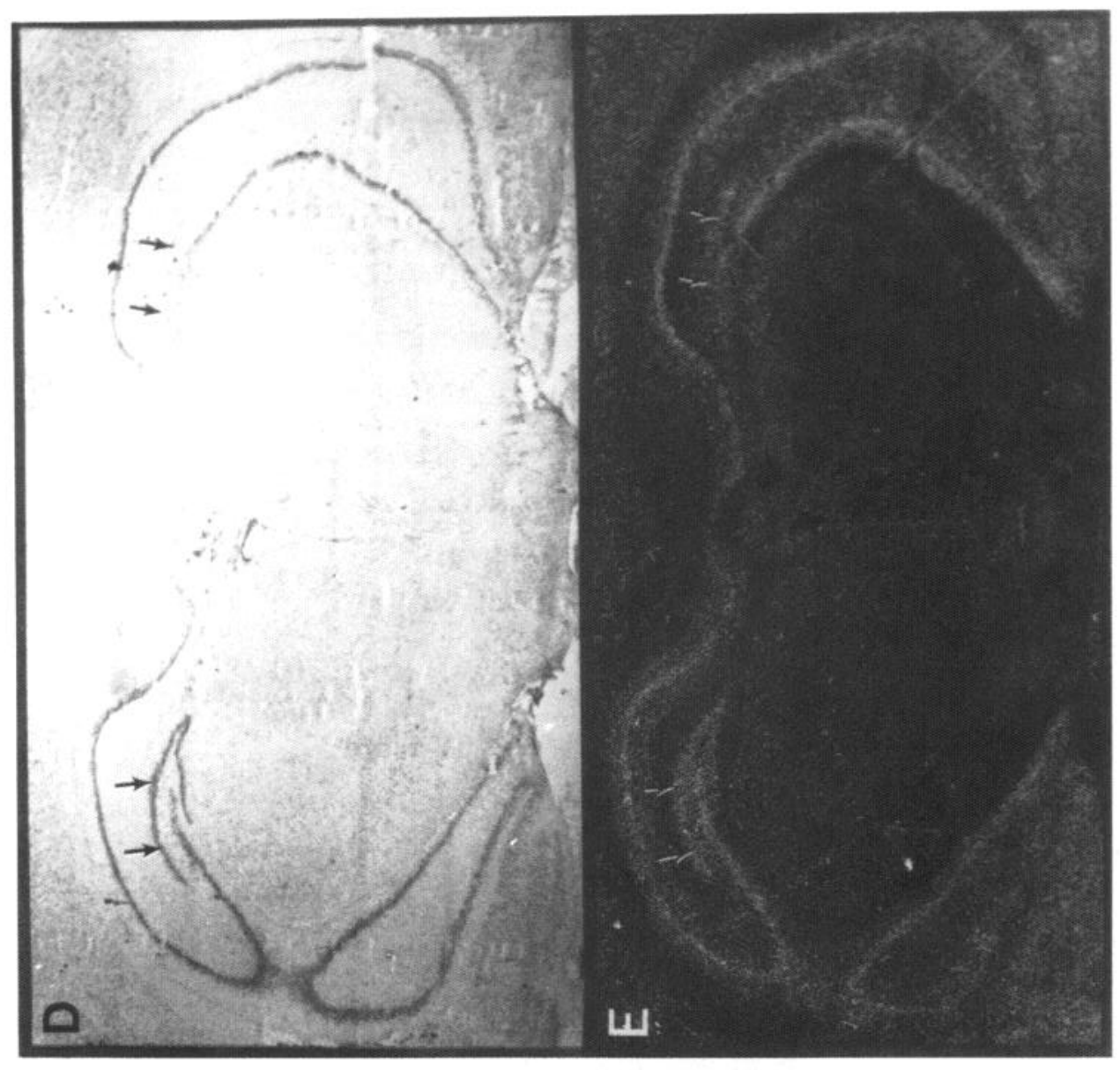

굴

逑

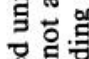

政

बै

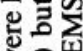

옹

诸安

तो

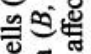

8 ङ

쳔횽

동

대을

氙

苋芩

․․휴

ㅎ․로

O. .5

S

气邹

정

王

远

a

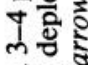

ชิธి

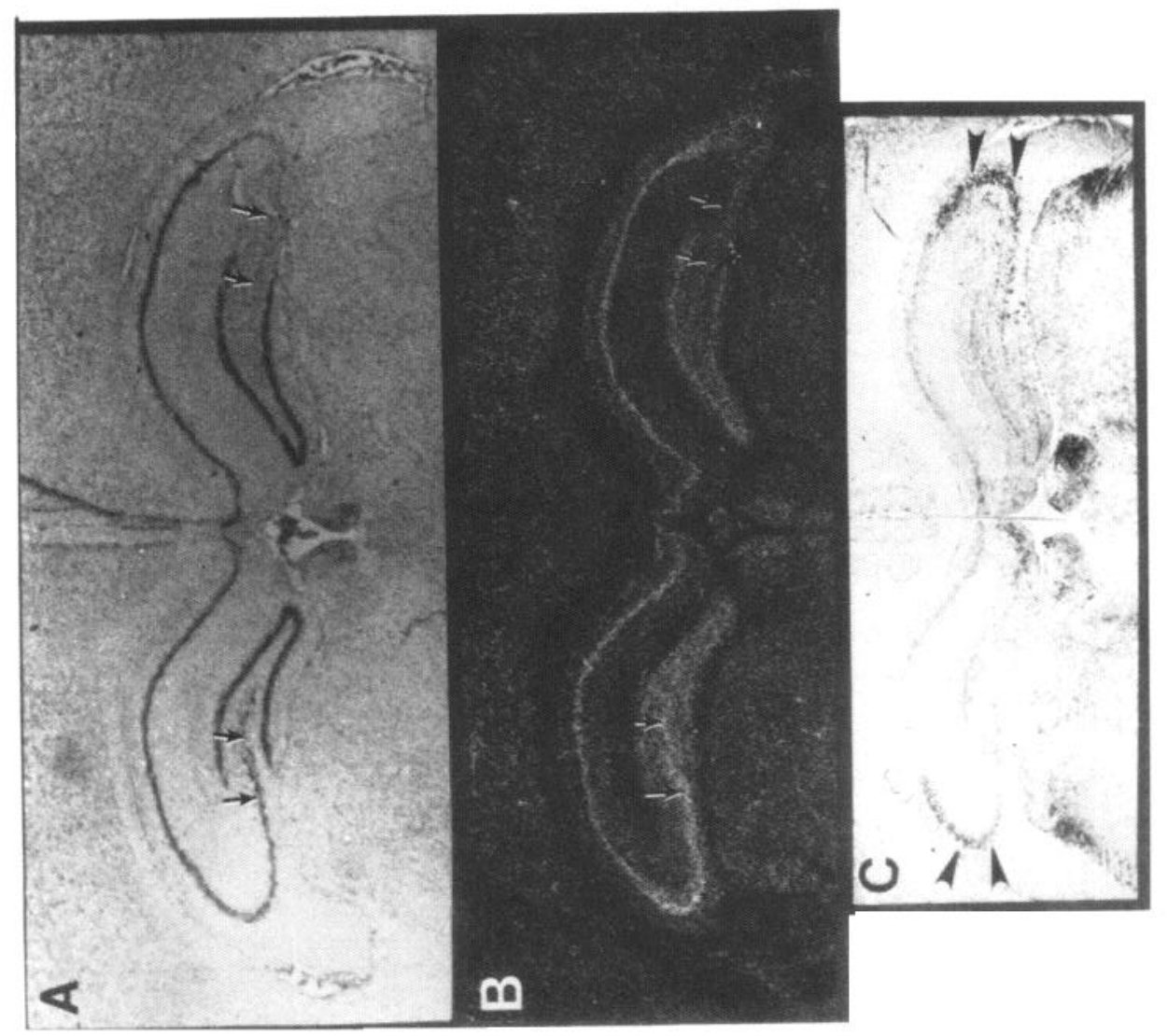

颉

정 정

릉

음음

을

宇

ज詻

色

란

它它

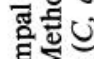

叟艺

응도

刍鱼

密

毛焉焉

형

등

8 .

陼

टि

岦要卷

홀 존

o

논등즌 

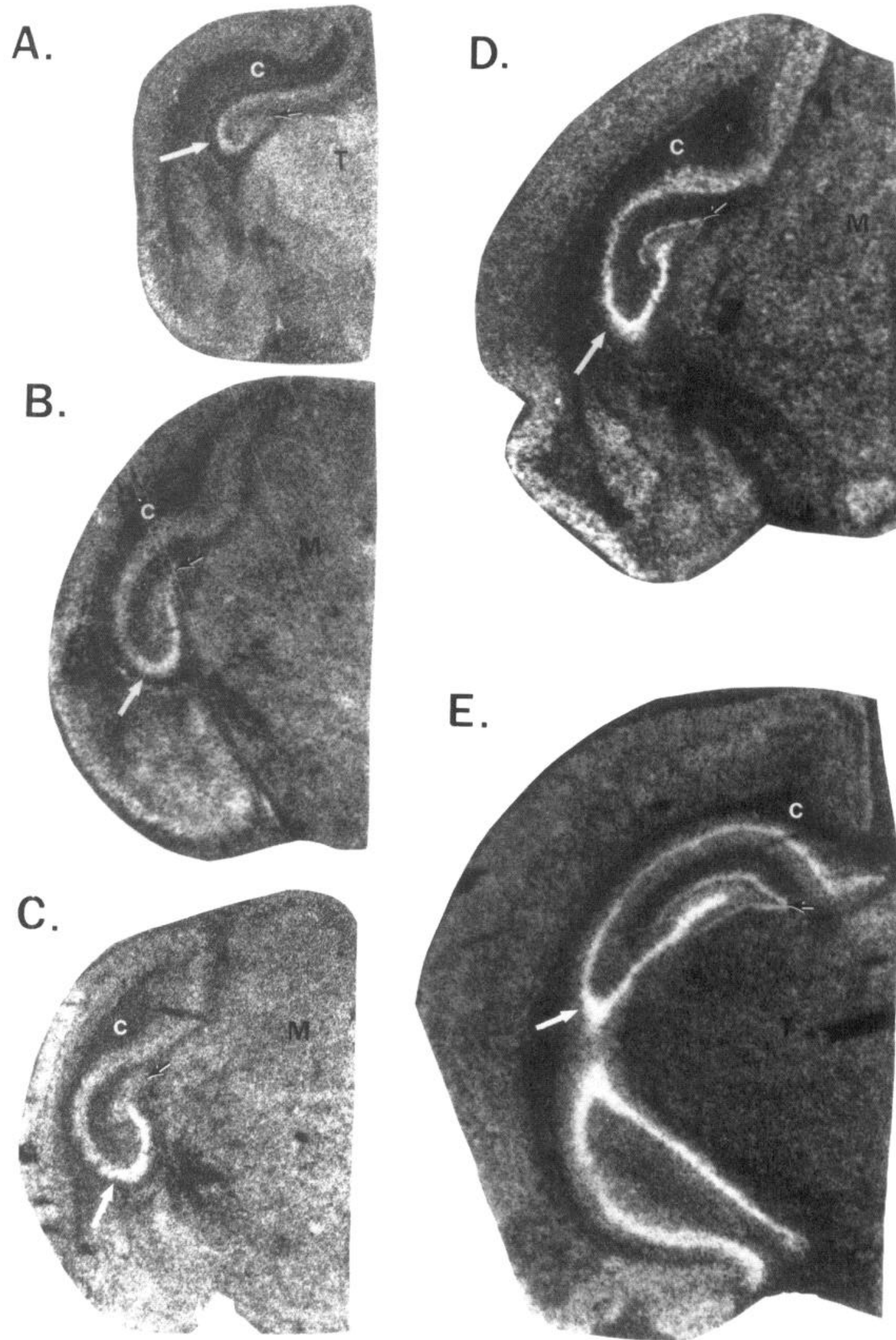

Figure 8. Development of EC in the hippocampal formation. The developmental course of ${ }^{3} \mathrm{H}$-GEMSA binding in the hippocampus is shown here for sections from rats at prenatal day $3(A)$, postnatal day $2(B)$, postnatal day $3(C)$, postnatal day $6(D)$, and postnatal day $20(E)$. EC develops first around the hippocampal pyramidal cell area (white arrow) and later in the dentate gyrus (black arrow). The external capsule (c) and thalamus $(t)$ or midbrain $(M)$ are labeled for reference. 

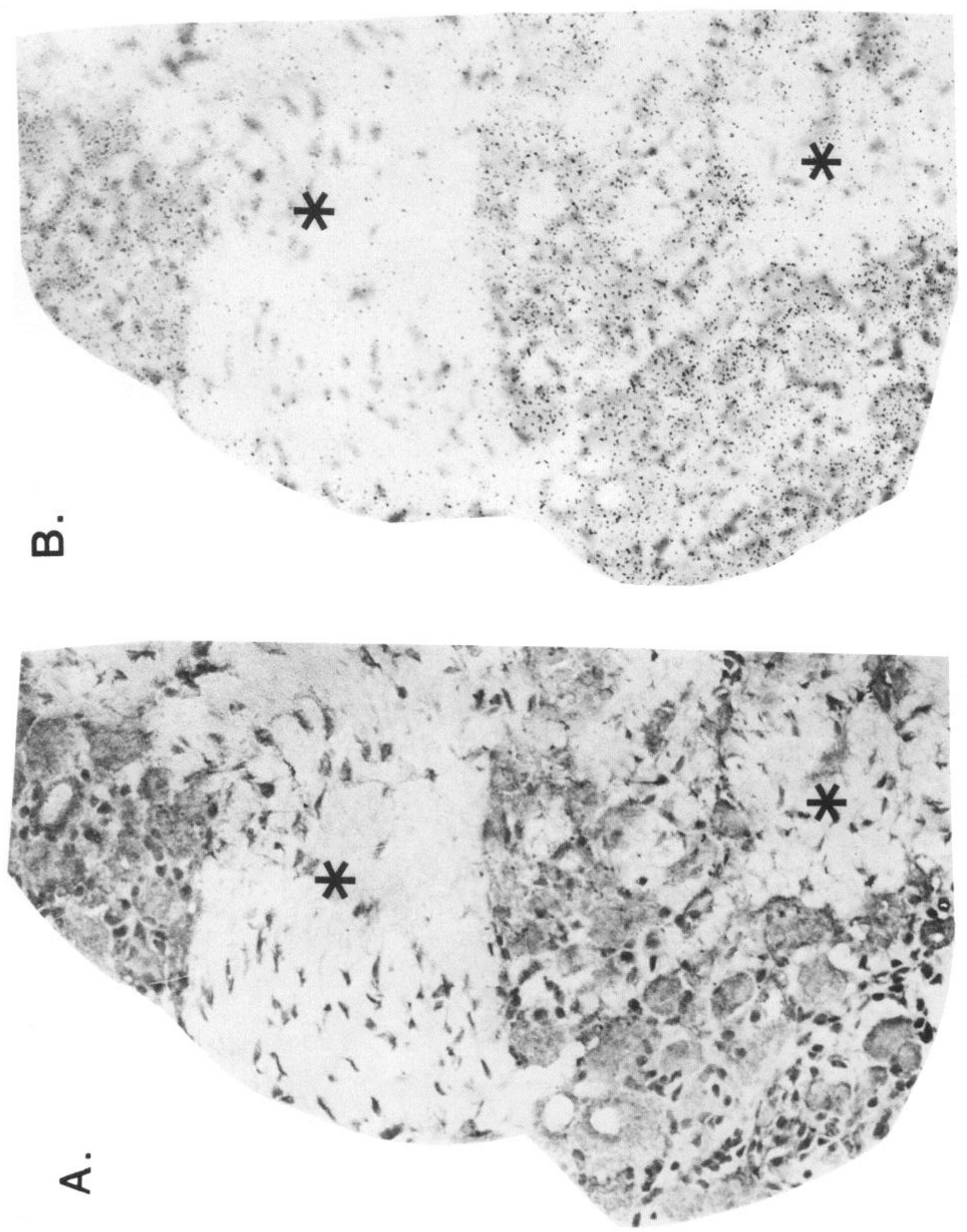
layer, the majority of binding is associated with intrinsic hippocampal neurons and not with hippocampal afferents or glia in the hippocampus.

A kainic acid lesion that selectively destroys the pyramidal cells of CA 3-4 is shown in Figure 7. Cholinesterase staining confirms that hippocampal afferents to CA 3-4 are left intact (Fig. 7C). Binding in the dentate gyrus and around CA $1-2$ is unaffected by this lesion, while the binding around CA $3-4$ is depleted. Thus, EC here is localized to the pyramidal cells or possibly to small interneurons in the pyramidal cell area and not to the mossy fibers originating in the dentate gyrus. This conclusion is supported by lesions of the granule cells with colchicine (Fig. 7, $D$ and $E$ ). This lesion removes some of the binding in the dentate gyrus but does not affect binding in the area around $\mathrm{CA} 3-4$. The binding remaining in the dentate gyrus is likely associated with the same afferents demonstrated by the quinolinic acid lesion. The binding that is destroyed in the dentate gyrus is probably associated with the granule cells. This lesion clearly demonstrates that the binding around CA 3-4 of the hippocampus is not associated with the granule cell mossy fiber projection, as the binding is not destroyed by this lesion. Accordingly, the pyramidal cells of CA 3-4, the afferents to the inner portion of the molecular layer, and probably the dentate gyrus granule cells contain EC.

Studies of EC development in the hippocampus agree with these localizations. The granule cells develop late in the rat, and most do not undergo their final division until after birth (Altman, 1966). However, high levels of ${ }^{3} \mathrm{H}$-GEMSA binding are present in the hippocampus at least $3 \mathrm{~d}$ before birth (Fig. 8). There is increased binding around CA 3-4 but only a small amount of binding in the area that will become the dentate gyrus. Over the next $9 \mathrm{~d}$ of development, the binding in the dentate gyrus reaches adult levels and is distributed in the same pattern as in the adult. Since the mossy fiber projection from the dentate gyrus to the stratum lucidum around CA 3-4 develops in the postnatal period (Amaral and Dent, 1981), the high levels around CA 3-4 before birth cannot be associated with this pathway. The development of EC in the dentate gyrus around postnatal days $3-5$ is likely associated with the granule cells or their afferents. Thus, both the developmental and lesioning studies suggest that EC in the hippocampal formation is associated with the hippocampal pyramidal cells, as well as with the granule cells or their afferents.

\section{Localization in the trigeminal ganglion}

The large size of the hippocampal pyramidal cells and the granule cells makes them amenable for studying EC localization. The cells of the trigeminal ganglia are also easily accessible and so have been examined by autoradiography with ${ }^{3} \mathrm{H}-\mathrm{GEMSA}$. In the trigeminal ganglion, ${ }^{3} \mathrm{H}$-GEMSA binding is localized to sensory neurons and not to the white matter tracts passing through the ganglion (Fig. 9). The grains are associated with a majority of the ganglion cells, although the exact proportion cannot be quantitated by autoradiography.

\section{Discussion}

The present study indicates an association of EC with enkephalin-containing brain regions but not only with those regions. The general distribution of EC in the rat forebrain resembles that of enkephalins, with the highest levels in the hypothalamus, the amygdala, the lateral septum, and the bed nucleus of the stria terminalis (Petrusz et al., 1985). In particular, EC localization corresponds closely to enkephalins and proenkephalin B-derived peptides in the central nucleus of the amygdala and the magnocellular nuclei of the hypothalamus. The heterogeneous distribution of EC in the cerebral cortex, with higher levels in the primary olfactory and entorhinal areas, is also consistent with a role in proenkephalin processing. However, many of these regions contain other peptide neurotransmitters, including neurotensin and substance $\mathrm{P}$ (Ljundahl et al., 1978; Uhl et al., 1977).

The studies conducted here likely localize only the membranebound form of EC. Using the tissue preparation conditions described here, previous studies have shown that soluble angiotensin-converting enzyme (Strittmatter and Snyder, 1984) and benzodiazepine receptors (Lo et al., 1983) are not detected by autoradiography. In the anterior pituitary, the levels of EC detected by autoradiography match the distribution of membranebound but not soluble EC (Strittmatter et al., 1985). Thus, ${ }^{3} \mathrm{H}-$ GEMSA autoradiography localizes only one form of EC. We attempted to retain the soluble form in the tissue sections by fixation with increasing concentrations of paraformaldehyde prior to incubation with ${ }^{3} \mathrm{H}$-GEMSA. However, this resulted only in the inhibition of binding activity.

The lesion studies of the stria terminalis demonstrate the presence of EC in one enkephalinergic pathway. The stria terminalis projects from the central nucleus of the amygdala to the bed nucleus of the stria terminalis and has previously been shown to contain enkephalins and neurotensin (Uhl and Snyder, 1979; Uhl et al., 1977, 1978). The present study shows that, like enkephalins and neurotensin, EC is axonally transported in the stria terminalis, accumulating posterior to transections of the stria and diminishing anterior to such lesions. Such lesions do not fully deplete enkephalins or EC from the bed nucleus of the stria terminalis, probably because both $\mathrm{EC}$ and enkephalins occur in interneurons in the bed nucleus (Uhl et al., 1978).

In a few other regions of the forebrain the distribution of $\mathrm{EC}$ does not parallel that of enkephalins. The levels of $\mathrm{EC}$ in the caudate-putamen and globus pallidus are low compared to the amount of enkephalins. Enkephalins here occur within striatopallidal and, with substance $\mathbf{P}$, in a striatonigral pathway (Correa et al., 1981; Cuello and Paxinos, 1978; Jessell, 1982). Despite the low levels of EC in these regions, the striatonigral lesion studies indicate that EC is present in a striatonigral pathway. The low levels of EC in the caudate may reflect reduced peptide processing in this pathway. In the caudate, globus pallidus, and substantia nigra, levels of $\alpha$-neoendorphin are approximately $5 \times$ greater than $\beta$-neoendorphin (Seizinger et al., 1984; Zamir et al., $1984 \mathrm{~b}, \mathrm{c})$. Since the production of $\beta$-neoendorphin from $\alpha$-neoendorphin can be catalyzed by a carboxypeptidase B-like processing enzyme, the lower levels of EC observed here may explain the alteration in the ratios of the neoendorphins.

The distribution of EC contrasts with that of enkephalins in the hippocampal formation. The inputs and projections of the hippocampal formation have been relatively well characterized (Walaas, 1983). The dentate gyrus receives input onto its molecular layer from the entorhinal cortex and from the septum, and the granule cells of the dentate gyrus project through the mossy fibers to the pyramidal cells of regions CA 3-4 of the hippocampus. The CA 3 pyramidal cells project to the CA 1 pyramidal cells, the septum, the subiculum, and the entorhinal cortex. Enkephalin levels are relatively low in the hippocampal formation and have been localized immunocytochemically to the perforant pathway from the entorhinal cortex (Gall et al., 1981), while proenkephalin B-derived peptides are found in the mossy fiber pathway within the hippocampal formation (Chavkin et al., 1985; McGinty et al., 1983). However, our lesion studies suggest that EC in this region has a different distribution. The majority of hippocampal EC is present in the hippocampal pyramidal cells and in afferents to the inner portion of the molecular layer of the dentate gyrus. Lesser amounts of EC may colocalize with EC in dentate gyrus granule cells.

The developmental course of EC in the hippocampus is consistent with the localization of EC to pyramidal cells. EC is found in the hippocampus at embryonic day 20 , while the mossy fiber 
pathway from the dentate gyrus to the hippocampus develops after birth (Amaral and Dent, 1981). This result supports the conclusion that EC develops first in the pyramidal cells of the hippocampus. EC levels in the dentate gyrus are low before birth in the rat but by day 5 after birth resemble the adult distribution. This is consistent with the development of $\mathrm{EC}$ in either the granule cells, many of which undergo their final division after birth, or in the afferents to the granule cells. The afferents to the granule cells develop mainly after postnatal day 4 (Crain et al., 1973) so that the developmental course of EC agrees with the evidence from lesion studies that $\mathrm{EC}$ is found in granule cell afferents. Enkephalin-like immunoreactivity develops in the hippocampus after birth, so that the development of EC here precedes that of enkephalins (Gall et al., 1984). Interestingly, the hippocampal pyramidal cells are not thought to contain enkephalin; thus, EC in these cells presumably acts on substrates other than enkephalin precursors. However, as yet no peptide neurotransmitters have been found within the pyramidal cells (Walaas, 1983)

EC may also process peptides other than enkephalin precursors in the trigeminal ganglion. ${ }^{3} \mathrm{H}$-GEMSA binding is discretely localized to the sensory cells with low levels in the white matter. The autoradiographic studies do not differentially localize EC to the sensory versus the satellite cells. However, given the strong association of EC with gray matter regions in the brain, the enzyme is likely to be found in sensory cells. The sensory cells do contain VIP, substance $P$, calcitonin gene-related peptide, and, in some cases, may contain an excitatory amino acid neurotransmitter (Hunt, 1983). However, there is no evidence that they contain enkephalins. Thus, EC here presumably is involved in the metabolism of other peptides.

\section{References}

Altman, J. (1966) Autoradiographic and histological studies of postnatal neurogenesis. II. A longitudinal investigation of the kinetics, migration and transformation of cells incorporating tritiated thymidine in infant rats with special reference to postnatal ncurogencsis in some brain regions. J. Comp. Neurol. 128: 431-474.

Amaral, D. G., and J. A. Dent (1981) Development of the mossy fibers of the hippocampus. I. A light and electron microscopic study of the mossy fibers and their expansions. J. Comp. Neurol. 195: 51-86.

Boarder, M., A. J. Lockfeld, and J. D. Barchas (1982) Met-enkephalin Arg-Phe immunoreactivity in bovine caudate and bovine adrenal medulla. J. Neurochem. 39: 149-154.

Chavkin, C., W. J. Shoemaker, J. McGinty, A. Bayon, and F. Bloom (1985) Characterization of the prodynorphin and proenkephalin neuropeptide systems in rat hippocampus. J. Neurosci. 5: 808-816.

Comb, M., P. Seeburg, J. Adelman, L. Eiden, and E. Herbert (1982) Primary structure of the human met- and leu-enkephalin precursor and its mRNA. Nature 295: 663.

Correa, F. M. A., R. B. Innis, L. D. Hester, and S. H. Snyder (1981) Diffuse enkephalin innervation from caudate to globus pallidus. Neurosci. Lett. 25: 63-68.

Crain, B., C. Cotman, D. Taylor, and G. Lynch (1973) A quantitative electron microscopic study of synaptogenesis in the dentate gyrus of the rat. Brain Res. 63: 195-204.

Cuello, A. C., and G. Paxinos (1978) Evidence for a long leu-enkephalin striopallidal pathway in rat brain. Nature 271: 178-180.

Docherty, K., and D. F. Steiner (1982) Posttranslation proteolysis in polypeptide hormone biosynthesis. Annu. Rev. Physiol. 44: 625.

Fricker, L. D., and S. H. Snyder (1982) Enkephalin convertase: Purification and characterization of a specific enkephalin synthesizing carboxypeptidase localized to adrenal chromaffin granules. Proc. Natl. Acad. Sci. USA 79: 3886.

Fricker, L. D., and S. H. Snyder (1983) Purification and characterization of enkephalin convertase, an enkephalin synthesizing carboxypeptidase. J. Biol. Chem. 258: 10950.

Fricker, L. D., T. H. Plummer, and S. H. Snyder (1983) Enkephalin convertase: Potent, selective and irreversible inhibitors. Biochem. Biophys. Res. Commun. 111: 994.

Gall, C., N. Brecha, K. J. Chang, and H. J. Karten (1981) Localization of enkephalin-like immunoreactive to identified axonal and neuronal populations of the rat hippocampus. J. Comp. Neurol. 198: 335-350.

Gall, C., N. Brecha, K. J. Chang, and H. J. Karten (1984) Ontogeny of enkephalin-like immunoreactivity in the rat hippocampus. Neuroscience 11: 359-379.

Gulber, U., P. Seeburg, B. J. Kaffman, L. P. Gage, and S. Udenfriend (1982) Molecular cloning establishes proenkephalin as a precursor of enkephalin-containing peptides. Nature 295: 206.

Hunt, S. P. (1983) Cyotochemistry of the spinal cord. In Chemical Neuroanatomy, Piers C. Emson, ed., pp. 53-84, Raven, New York.

Jessell, T. (1982) Substance P in the nervous system. In Handbook of Psychopharmacology, L. L. Iversen, S. D. Iversen, and S. H. Snyder, eds., Vol. 16, pp. 1-105, Plenum, New York.

Kakidani, H., Y. Furutani, H. Takanishi, M. Noda, Y. Morimoto, T. Hirose, M. Asai, S. Inayana, S. Nakanishi, and S. Numa (1982) Cloning and sequence analysis of cDNA for porcine $\beta$-neoendorphin/ dynorphin precursor. Nature 298: 245 .

Kimura, S., R. V. Lewis, A. S. Stern, J. Rossier, S. Stein, and S. Udenfriend (1980) Probable precursors of leu-enkephalin and met-enkephalin in adrenal medulla: Peptides of 3-5 kilodaltons. Proc. Natl. Acad. Sci. USA 77: 1681-1685.

Kuhar, M. J., P. J. Whitehouse, J. R. Unnerstall, and H. Loats (1984) Receptor autoradiography: Analysis using a PC-based imaging system. Soc. Neurosci. Abstr. 10: 558.

Lewis, R. V., A. S. Stern, J. Rossier, S. Stein, and S. Udenfriend (1979) Putative enkephalin precursors in bovine adrenal medulla. Biochem. Biophys. Res. Commun. 89: 822-829.

Ljungdahl, A., T. Hökfelt, and G. Nilsson (1978) Distribution of substance P-like immunoreactivity in the central nervous system of the rat. I: Cell bodies and nerve terminals. Neuroscience 3: 861-943.

Lo, M. M. S., D. L. Niehoff, M. J. Kuhar, and S. H. Snyder (1983) Autoradiographic differentiation of multiple benzodiazepine receptors by detergent solubilization and pharmacologic specificity. Neurosci. Lett. 39: 37-44.

Lynch, D. R., S. M. Strittmatter, and S. H. Snyder (1984) Enkephalin convertase localization by $\left[{ }^{3} \mathrm{H}\right]$-guanidinoethylmercaptosuccinic acid autoradiography: Selective association with enkephalin containing neurons. Proc. Natl. Acad. Sci. USA 81: 6543.

McGinty, J. F., S. J. Henrikson, A. Goldstein, L. Terenius, and F. Bloom (1983) Dynorphin is contained within hippocampal mossy fibers: Immunochemical alterations after kainic acid administration and colchicine induced neurotoxicity. Proc. Natl. Acad. Sci. USA 80: 589593.

Noda, M., Y. Furutani, M. Takahashi, T. Hirose, S. Inagama, S. Nahanishi, and S. Numa (1982) Cloning and sequence analysis of cDNA for bovine adrenal preproenkephalin. Nature 295: 202.

Petrusz, P., I. Merchenthaler, and J. L. Maderdrut (in press) Handbook of Chemical Neuroanatomy, Elsevier, New York.

Ralis, H. M., R. A. Beesley, and Z. A. Ralise (1973) Techniques in Neurohistology, Butterworths, London.

Schwarz, R., W. D. Whetsell, Jr., and R. M. Mangano (1983) Quinolinic acid: An endogenous metabolite that produces axon-sparing lesions in rat brain. Science 219: 316-318.

Seizinger, B. R., C. Grimm, V. Hollt, and A. Herz (1984) Evidence for a selective processing of proenkephalin $B$ into different opioid forms in particular regions of rat brain and pituitary. J. Neurochem. 42: 447-457.

Strittmatter, S. M., and S. H. Snyder (1984) Angiotensin converting enzyme in the male reproductive system: Autoradiographic visualization with $\left[{ }^{3} \mathrm{H}\right]$ captopril. Endocrinology 115: 2332-2341.

Strittmatter, S. M., M. M. S. Lo, J. A. Javitch, and S. H. Snyder (1984a) Autoradiographic visualization of angiotensin converting enzyme in rat brain with $\left[{ }^{3} \mathrm{H}\right]$ captopril: Localization to a striatonigral pathway. Proc. Natl. Acad. Sci. USA 81: 1599.

Strittmatter, S. M., D. R. Lynch, and S. H. Snyder (1984b) $\left[{ }^{3} \mathrm{H}\right]-$ Guanidinoethylmercaptosuccinic acid binding to tissue homogenates: Selective labeling of enkephalin convertase. J. Biol. Chem. 259: 11812 11817.

Strittmatter, S. M., D. R. Lynch, and S. H. Snyder (1985) Enkephalin convertase demonstrated in the pituitary and adrenal gland by $\left[{ }^{3} \mathrm{H}\right]-$ guanidinoethylmercaptosuccinic acid autoradiography: Dehydration decreases neurohyphophyseal levels. Endocrinology 117: 1667-1674.

Supattapone, S., L. D. Fricker, and S. H. Snyder (1984) Purification and characterization of a membrane bound enkephalin-forming carboxypeptidase, "enkephalin convertase." J. Neurochem. 42: 1017. 
Uhl, G. R., and S. H. Snyder (1979) Neurotensin: A neuronal pathway projecting from amygdala through stria terminals. Brain Res. 161: 522-526.

Uhl, G. R., M. J. Kuhar, and S. H. Snyder (1977) Neurotensin: Immunohistochemical localization in rat central nervous system. Proc. Natl. Acad. Sci. USA 74: 4059-4063.

Uhl, G. R., M. J. Kuhar, and S. H. Snyder (1978) Enkephalin containing pathway: Amygdaloid efferents in the stria terminalis. Brain Res. 149: 522-526.

Unnerstall, J. R., D. L. Niehoff, M. J. Kuhar, and J. M. Palacios (1982) Quantitative receptor autoradiography using $\left[{ }^{3} \mathrm{H}\right]$ Ultrofilm: Application to multiple benzodiazepine receptors. J. Neurochem. Methods 6: 59-73.

Walaas, I. (1983) The hippocampus. In Chemical Neuroanatomy, Piers C. Emson, ed., pp. 337-358, Raven, New York.
Young, W. S., III, and M. J. Kuhar (1979) A new method for receptor autoradiography: $\left[{ }^{3} \mathrm{H}\right]$ opioid receptors in rat brain. Brain Res. 179 255-270.

Zamir, N., E. Weber, M. Palkovits, and M. Brownstein (1984a) Differential processing of prodynorphin and proenkephalin in specific regions of the rat brain. Proc. Natl. Acad. Sci. USA 81: 6886-6889.

Zamir, N., M. Palkovits, and M. Brownstein (1984b) The distribution of immunoreactive alpha neoendorphin in the central nervous system of the rat. J. Neurosci. 4: 1240-1247.

Zamir, N., M. Palkovits, and M. Brownstein (1984c) Distribution of immunoreactive beta neoendorphin in discrete areas of the rat brain and pituitary gland: Comparison with alpha neoendorphin. J. Neurosci. 4: $1248-1252$. 